DOSSIÊ TEMÁTICO: Formação inicial de professores em contextos escolares e binômio teoria/prática nos estágios supervisionados

do/ https://doi.org/10.22481/rpe.v16i43.6908

\title{
FORMAR UM PROFESSOR COMPETENTE: POR UM ENSINO PEDAGÓGICO, PROMOVENDO UMA SUBJETIVIDADE AUTÊNTICA
}

\author{
TRAINING A COMPETENT TEACHER: FOR A PEDAGOGICALLY ORIENTED \\ TEACHING, PROMOTING AN AUTHENTIC SUBJECTIVITY
}

FORMAR A UN MAESTRO COMPETENTE: PARA UNA ENSEÑANZA PEDAGÓGICAMENTE ORIENTADA, PROMOVIENDO UNA AUTÉNTICA SUBJETIVIDAD

Riccardo Pagano
Università degli Studi di Bari Aldo Moro - Italy

Adriana Schiedi

Università degli Studi di Bari Aldo Moro - Italy

\begin{abstract}
Resumo: A questão do profissionalismo dos professores em todos os níveis de ensino está entre as mais urgentes que a pedagogia enfrenta atualmente. Atualmente, a sociedade cada vez mais complexa exige que o professor tenha uma competência educacional / didática de qualidade capaz de incentivar nos alunos uma aprendizagem bem estruturada e o desenvolvimento de uma autêntica subjetividade personalizada. Nessa perspectiva, as análises feitas por E. Stein sobre a formação de professores para torná-los competentes na construção de processos de conhecimento (gnoseologia), em epistemologias disciplinares e sobre as formas de regular a formulação do julgamento (lógica) devem ser considerado valioso. A partir dessa aquisição, essa contribuição meditará sobre como atualmente um professor pode ser treinado pedagogicamente para ser competente, tanto na estrutura disciplinar quanto na identificação dos objetivos educacionais do conhecimento aprendido. Como veremos, o conhecimento, a epistemologia das disciplinas e a lógica do pensamento, longe de representar apenas o propósito do ensino, constituirão os meios pelos quais o professor promoverá uma maneira de ensinar orientada no sentido fenomenológico-hermenêutico, como o criador e desenvolvedor da autonomia do julgamento e da responsabilidade relacionada ao valor.
\end{abstract}

Palavras chave: Formação; Professor; Ensino pedagógico.

Abstract: The issue concerning professionalism of teachers at all levels of education is among the
most urgent ones that pedagogy is facing today. Nowadays, the increasingly complex society requires
the teacher to have a quality educational/didactic competence able to encourage a well-structured
learning and the development of an authentic personalized subjectivity in the students.
In this perspective, the analyses made by E. Stein concerning teachers' training to make them
competent in the building of knowledge processes (gnoseology), in disciplinary epistemologies, and
the ones concerning the ways to regulate the formulation of judgment (logic), must be considered 
valuable. Starting from this acquisition, this contribution will meditate on how nowadays a teacher can be pedagogically trained to be competent, both in the disciplinary structure and in identifying the educational aims of the learnt knowledge. As we will see, knowledge, the epistemology of disciplines and the logic of thinking, far from representing only the purpose of teaching, will constitute the means by which the teacher will promote a way of teaching oriented in a phenomenological-hermeneutical sense, as creator and developer of autonomy of judgment and of value-related responsibility.

Keywords: Training; Teacher; Pedagogically oriented Teaching.

Resumen: El tema de la profesionalidad de los docentes en todos los niveles de educación es uno de los problemas más urgentes que enfrenta la pedagogía en la actualidad. Hoy en día, la sociedad cada vez más compleja exige que el maestro tenga una competencia educativa / didáctica de calidad capaz de alentar a los estudiantes a tener un aprendizaje bien estructurado y el desarrollo de una auténtica subjetividad personalizada. En esta perspectiva, los análisis realizados por E. Stein sobre la capacitación de docentes para hacerlos competentes en la construcción de procesos de conocimiento (gnoseología), en epistemologías disciplinarias y sobre las formas de regular la formulación del juicio (lógica) deben considerarse valiosos. A partir de esta adquisición, esta contribución meditará en cómo actualmente un maestro puede ser entrenado pedagógicamente para ser competente, tanto en la estructura disciplinaria como en la identificación de los objetivos educativos del conocimiento aprendido. Como veremos, el conocimiento, la epistemología de las disciplinas y la lógica del pensamiento, lejos de representar solo el propósito de la enseñanza, constituirán los medios por los cuales el maestro promoverá una forma de enseñanza orientada en el sentido fenomenológicohermenéutico, como creador y desarrollador de autonomía de juicio y responsabilidad relacionada con el valor.

Palabras clave: Formación; Profesor; Enseñanza pedagógica.

\section{Training a "competent" teacher: pedagogical focus}

In recent years, the emphasis of the quality construct, as a commitment and objective to which the training process must aim, has promoted a profound rethinking of the educational-teaching competence and an increasing attention to the training of teachers with the aim of carrying out a educational project more responsive to users' needs and to the new training needs of contemporary society. The alliance that has been created between the world of school and that of the university has emphasized a series of questions to which the most mature pedagogical-didactic research is trying to answer (DAMIANO, 2006) ${ }^{1}$. First of all: who is the teacher, recipient of the courses and teaching pathways? What is his physical, psychic nature, what are his beliefs, his aspirations, what is the ethos, the motivation that drives him to undertake this complex yet fascinating job? And again: what is the teacher's task/role? What does his competence consist of and how is it articulated? In an attempt to

\footnotetext{
* The project of the contribution was shared by the two authors and independently developed in different sections: Adriana Schiedi is the author of paras. 1-2; Riccardo Pagano of paras. 3-4.
} 
answer to these and many other questions, pedagogy seems to have uncovered a Pandora's box which pours out an increasing complexity of problems related to the role of the teacher and his initial and in-service training.

This is a complexity that undoubtedly challenges the world of school, politics, society tout court, but above all the university with the aim of reviewing current training paths to understand their critical issues and, starting from these, to remodel them or design new ones. Yet, despite the significant progress made in pedagogical-didactic research in recent years, teaching remains that unrecognized object, that thematic crossroads, that nobody's land on which more or less everyone, including academics, disciplinary and non, always feels the need to express theories by indicating more or less valid paths for teaching and learning, flying over epistemological issues concerning the lawfulness, validity, but above all the scientific, theoretical foundations of these paths (LANEVE, 2017, p. 16). This occurs because of a basic misunderstanding: the educational-teaching action, in fact, should not be understood only as a mechanical action of transmission and reception of messages and learning contents, but it is much more. The "conceptual clarifications" and the "theoretical reference coordinates" (LANEVE, 2017, p. 13). of the teaching must be traced in the docimological-didactic science, which is to say in that knowledge of a still pedagogical nature that since the mists of time and, even before Comenius, in ancient Greece, addresses its specific reflection to the art of teaching and to the problems connected with the training of various subjects, in different ages and in different contexts.

It is a widespread area that objectively pedagogy, in its teaching capacity, cannot govern on its own: the perspective is the systemic one that recalls the need for multiple glances on the world of teaching/learning, school and university, on teachers and their training (LANEVE, 1993). With a warning, however, it is worth underlining, that the direction of this "dialectical game" with the other knowledge is of pedagogy, and that from this synergy of glances it "receives an enrichment-thickening-condensation contribution" (LANEVE, 200, p. 246) in sight of a "critical revision of its assumptions", of a "rationalization of its procedures" and of an "optimization of its resources", especially the human ones, meaning teachers with these latter. Today's pedagogical-didactic research pays special attention to teachers, teaching professionals (ALTET, 2006). This in the clear awareness that they represent the true custodians of the educational-teaching art: "they have implicit didactic models that support their professional activities and have a wealth of tacit knowledge that must be [analyzed first and then] converted into organized knowledge" (LANEVE, 2000, p. 245). 
Hence the development of a line of research, known as Analysis of educational practices (ALTET, 2006, p. 11), renamed with the expression Teacher Education ${ }^{2}$ in 2012, marked by a multiplicity of approaches, among which we mention: pragmatic, ergonomic, cognitive, clinical, ethnomethodological, phenomenological, biographic-narrative, deconstructionist, evidence based, micro-sociological, systemic, international, socioconstructivist, practical-reflective, research-action. There are many scholars, and among them we remember M. Altet, E. Bautier, D. Flablet, C. Laneve, Ph. Perrenoud, M. Postic et alii who, by adhering to this research paradigm, believe that to shed light on that "opaque microcosm" which teaching is and knowing the quid of the educational-teaching action, rather than simply collecting the opinions of the direct protagonists, very often misrepresented by distorted images fed by memory, by false idola, by implicit reference models not adhering to reality, it is necessary to learn to observe and interpret what the teacher does in concrete work situations. Today, research on the analysis of educational practices testifies not only, would say T.S. Kuhn (1969), a fundamental "paradigm shift" in the investigation of teaching - from a deductive (theoretical-practical) model to an inductive (practical-theoretical) one - , but also a new way of thinking and promoting teacher training (BALDACCI, 2011). In fact, it abandons the old disciplinary and stereotyped approach to elevate itself to a training model in continuous updating and redefinition, contextualized, individualized, custom designed, which puts the teacher in the position of leading actor. He, as claimed by H.-G. Gadamer, will build his professionalism on the basis of experience, meaning through a vicarious reflection developed on real teaching situations experienced at first hand, from which he will derive schemes and maps of meaning that will act as coordinates of his practical knowledge and his educational-teaching competence. According to M. Postic, the analysis of educational practices will be the first step towards understanding teaching, observing it through what happens in the classroom (POSTIC, 1977). Taking into consideration the educational practice, deconstructing and observing it in its unfolding in the classroom and in the interpretation given by the actors involved is, for M. Altet, a necessary condition in order to know their thinking (which means «all that experiential and professional treasure made of mental images, metaphors, tacit knowledge that teachers have on how to teach, on how to solve some

\footnotetext{
2 The debate on Teacher Education is very heted not only in Italy but also in Europe and internationally. There is also an increase in the number of publications published about this topic, of which only a first general indication is offered here: cf. C. Day, C. Laneve (eds.), Analysis of Educational Practices. A comparison of Research Models, La Scuola, Brescia 2011; L. Fabbri, Formazione degli insegnanti e pratiche riflessive, Armando, Roma 1999; B. Ligorio, Come si insegna, come si apprende, Carocci, Roma 2003; L. Mortari, Ricercare e riflettere. La formazione del docente professionista, Carocci, Roma 2009; L. Perla, M. Tempesta (eds.), Teacher Education in Puglia. Università e scuola per lo sviluppo della professionalità docente, Pensa MultiMedia, Lecce 2016.
} 
teaching problems, on how to manage some situations in the classroom»), improve their training and build their own specific professional identity, through greater awareness of the meaning of the work they do. As highlighted by D. Schön (2006), it is the activation of reflection processes during the course of action that makes the teacher aware of his experience, an active and critical interpreter of the reference context and capable of living the relationship with the other in a constructive, promotional, enhancing way.

Based on these assumptions, teacher training is transformed into a process of pedagogical accompaniment, into a form of laboratory/tutoring in which the teacher is guided in the definition/acquisition and in the conscious and expert use of his knowledge. Researches conducted in this sense demonstrate how the teacher, in participating in this process of building his knowledge, shows the will to question himself and the desire to renew himself, to grow, to improve to change, as specified by $\mathrm{Ph}$. Perrenoud (1994), from an "artisan" dimension of his work, inspired by a positivist technical rationality, supported by a sectorial, scientific knowledge, sclerotized in the application of rigid rules and procedures, to a professionalism based on expertise, in which, together with the flexibility, singularity, originality, creativity are fundamental, meaning the personal imprint that assumes its knowledge on the basis of the experience, of the categorical, hermeneutic and value processes that qualify his person and his experience.

In fact, it should be taken into account that like every human action, also the teacher's action is an intentional doing that engages the whole person by involving it on the level of rational, human and relational logic, of the purposes and means of the educational act. Hence the nature of the practical knowledge of the professional competence of the teacher, which on the basis of what has been said, would result as a unity of meaning based on a series of variables such as subjectivity, uniqueness, motivational drive, gnoseologicity, disciplinarity, evaluativeness, methodology, experience and even extramethodicity (PAGANO, 2018).

These elements are indispensable for understanding what is taught, how it is taught, when, why, under what conditions it is useful to do so, what is the guiding idea that directs educational action.

This is an idea that - as observed by Husserl and his disciple E. Stein - always bears the signature of the author who thinks it, who creates it, who impresses it in reality by delivering it to the world and experience, often unaware of developments and the repercussions it will have on himself and on the context. When this occurs, there would be a 
disconnect between the theoretical teaching plan and the practical plan, which immediately, but above all in a long-term educational program, turn out to be as dangerous.

It is to counter this danger that the professionalism on which the most mature pedagogical-didactic research focuses today, as suggested by E. Stein and subsequently emphasized by many other theorists of pedagogical thought, among which we remember $\mathrm{G}$. Santomauro (PAGANO, 2008), is that which comes from a dialectical relationship between theory and practice, between methodological and axiological plan, and which precisely on the basis of this interaction and complementarity is capable of passing, as G. Le Boterf maintains, from "knowing how to knowing how to act", combining theoretical knowledge with ability practices to dominate the different situations encountered and optimize learning outcomes, through the choice of appropriate strategies. Today's teacher is asked to act more and more for "unique cases" (and not for standard situations as in the past), comparing the particular characteristics of the current situation with those of the past and developing new cognitive categories. In the complex process of teacher training/self-training, it comes, as you can easily guess, to developing a "phenomenological-hermeneutic awareness" and a critical look at what it does and how it does, striving (o trying) to seek meaning in one's own action, a greater and clearer validity in communicative exchanges with students, greater attention not only to the contents to be transmitted but also to the ways in which it is convenient to do so, therefore, to the disciplinary dimension but also practical and experiential, personal and relational of the educational process. Acquiring (o gaining) a phenomenological-hermeneutic awareness will mean, as we will see in the course of our discussion, developing the ability to combine these dimensions of knowledge in a balanced way, learning to recognize the situation, the case in front of you: achieving a clear knowledge of those elements and those characteristics that allow not to stereotype it but to categorize it, leading it back to a model acquired both on a disciplinary and methodological and experiential level. But not only: it also means analyzing between the possible alternatives of intervention and the various tools that allow you to observe, describe, interpret, narrate, document, those most suitable for the particular characteristics of the situation and context. As we will see in the next paragraph, only the mastery of a knowledge thus understood, a synthesis of disciplinary and experiential knowledge, of singularity, intentionality, gnoseologicity and methodology, the prudent choice of actions and the ability to connect them to a theoretical corpus of disciplinary knowledge with a Pedagogical purposes will be the precise measure of the competent teacher, capable of 
structuring and enriching himself through the realization of his work and reflection on it, and to promote human development and authentic subjectivity.

\section{About the logical articulation and pedagogical finalization of the teacher's knowledge}

The reflections developed in the 1926-1933 period by a great twentieth-century philosopher, Edith Stein (SCHIEDI, 2017), about the topic of teacher training are invaluable. Husserl's student and teacher of pedagogy in Münster, she gave several lectures about this subject, highlighting even then the indispensability of the question about teaching and teaching professionalism in the degree courses of Pedagogy. Questioning oneself on teaching means, Stein notes, understanding what it is made up of, how the knowledge of the teacher is articulated and, therefore, what competence it is necessary to promote in order to train expert teachers who are builders of authentic human beings: aware of their individuality and dignity and responsible to themselves, their neighbor and the community. Teaching as well as education is for Stein (2017) an "individual and social fact" whose theoretical foundations must be traced in a philosophical-educational anthropology declined in a phenomenological sense. In fact, the first question the teacher must ask himself is who is the teaching addressed to? So: who is the human person recipient of the educational-teaching intervention? And in return: what is the ontological structure of which it is composed? And again, what is the individuality intended to be developed? for which community? And with the contribution of which other agencies?

Given, moreover, that educating, training and instructing do not represent the same thing, what is the fil rouge that holds these three actions together by merging them into a single competence? Some useful food for thought to provide answers can be found in the title and content of one of her reports Wahrheit und Klarheit im Unterricht und in der Erziehung (STEIN, 2017, p. 5), held on 11 September in Spira at the pedagogical conference and on 12 September in Kaiserslautern. In this, the scholar explains that truth and clarity are the qualities the teacher can acquire primarily on the basis of a theory of knowledge and logic (STEIN, 2017, p. 5). It is through this knowledge, in fact, that the teacher can learn to ask himself about "what is knowledge? What possible types of knowledge do they give themselves? Under what conditions is authentic or valid knowledge possible? [...] Three factors belong to each knowledge: an object that is known, a subject or a spiritual being, that knows, and the activity or the act of knowing. [...] There are different types of knowledge, depending on the objects. [...] but also according to the subject to be known” (STEIN, 2017, p. 56). 
However, a first knowledge is also that which the teacher can derive from the observation of reality: a «purely passive first apprehension is followed by an additional activity (STEIN, 2017, p. 5), aimed at acquiring more information on the specific characteristics of the object / subject that one has of front, also through a comparison / relationship with other objects / subjects. In observing, the teacher sets his gaze on himself and others, on his own and others' actions. The ability to observe the whole and then the individual parts is linked to the ability to analyze, typical of a thought that can break down and then compose (STEIN, 2017, p. 8), which is capable of making a comparison and making judgments. A judgment can be true or false, based on its conformity with being, according to the principle of adaequatio rei et intellectus of scholasticism and St. Thomas. It is logical competence that gives the teacher the ability to make judgments but also to express concepts, clear and distinct (which reveal an intuition that is accompanied by a unitary understanding of the object in front of) intuitions (Anschauung) and to know how to argue. In his activity, the teacher is called to recognize the characteristics of the situation he faces, to evaluate the resources, the different options of actions, and then to decompose, to select, to choose, often based on an intuition or common sense, the best solution on the basis of the specificity of the context and the needs of the user. In these operations of analysis and decomposition of the objects of knowledge "the clearer the intuition, the greater the prospect of achieving true judgments and right concepts" (STEIN, 2017, p. 10). Since intuition always takes place by a subject, in this case the teacher, it is up to him that the educational-didactic work and the ability to instill in the students a knowledge made of true judgments, clear ideas and right concepts depends on him, to «train their intellect so they are able to independently acquire clear ideas, right concepts and true judgments (STEIN, 2017). Truth and clarity, explains Stein, are not only the end of the teaching but also the means: to become a mediator of authentic training, the teacher must have firsthand himself clear ideas and true judgments. And then "he must teach children to observe (anschauen) and to think, that is to say he must show them how they must observe and think, he must push them to observe and think with him and ultimately lead them to be able to carry out these activities autonomously even correctly" (STEIN, 2017, p. 11).

The principles of truth and clarity are central also in the educational work, in that process aimed at the formation of the human being as a whole which, beware, is not separated from teaching but, on the contrary, represents its core deep and the ultimate goal. In fact, the task of the teacher, as Laneve reminds us, "cannot end in a 'nice' explanation, not limit itself 
to transmitting knowledge, but must consist: - in helping the student to develop meaningful knowledge, making sense for his project of man; - in explaining to the same student which mental operations he / she will have to employ when solving a task [...]; being aware that each student has his own 'cognitive autobiography', [...] a way of being [...] to be strengthened, cultivated, refined; in feeding the conversation and the dialogue [...]; in increasing the problematization [...] educating to think" (LANEVE, 2017). Disciplinary knowledge, although necessary, as we will see more extensively in the following paragraph, proves to be vacant and ineffective if not supported and oriented by a pedagogical rationality centered on being and learning a framework of values useful to make the student grow, to promote him as a person in his individuality, responsibility, humanity, authenticity.

\section{Didactic knowledge as disciplinary knowledge}

Even now, in the 21 st century society whose knowledge is organized into disciplines (BALDACCI, 2010, p. 37), School represents a privileged place for formalized learning, which is unavoidable and undeniable.

Disciplinary knowledge is a knowledge system with its own self-generating organization. The different kinds of knowledge have an epistemological system which organizes them internally and which inserts them in the encyclopedia of formalized knowledge. The disciplines are «a logical- practical system, endowed with its objective existence, characterized by its own organization and capable of developing through its own resources in the sense of strengthening this organization» (Germain, 1978, p. 157).

First of all, let us clarify that disciplines are not, as they have often been understood, a set of notions. It is from the "epistemological turning point" (BACHELARD, 1934) of the 1940s, which became popular in Italy especially in the late 1960s, that epistemologists began to wonder about what a discipline is, and what its nature consists of.

A consideration grew from these requests, which led to clarify the bases of the disciplines, their internal logics and the research methods they adopt. Bruner acutely highlighted another aspect of noteworthy relevance concerning the nature and structure of the disciplines, if they are the same or not. According to Bruner, structure is in nature, but the opposite is not true: nature is not in structure (BRUNER, 1960).

When we speak about nature, we obviously refer to the subject of study of the discipline, to its gaze on the reality to investigate. It is clear that structures are needed to 
investigate. The disciplinary construction takes place on the structures and then the same structures interact with those of other kinds of knowledge and disciplines giving rise to the famous interdisciplinarity. This, in turn, gives rise to forms of hybridization, or even of crossbreeding. In the first case, knowledge advances, in the second, confusions can occur. Beyond these subtleties that it is not necessary to face here, it must be said that the disciplines are living organisms that modify their structures without altering their nature: that is, the formal object of study always remains firmly in place.

A form of knowledge with which, today, the disciplines have to deal with is, without a doubt, the "technique". It represents a kind of knowledge which is distinct from the epistème, a path which sometimes, however, proceeds in a correlated way. When this happens, science and technology tend to technocracy, that is, to domination. The "interpenetration" between science and technology, today, is so pushed forward that even all science results in technology and technology becomes the prevailing ideology replacing the philosophies of the 1900s history becoming the new metaphysics of which, in the Kantian way, we can say that we are all "in love" (SEVERINO, 1998). The replacement of anthropocentric humanism with technocentric humanism gives the illusion that every human problem can be solved through technique (ACONE, 1997)., Therefore, from being the object of knowledge of the men who use it, technique -and its derivative, technology becomes the subject of knowledge towards which men perform the function of object. The relationship is reversed: technology grows on itself and, to do that, it uses men.

Another relevant passage about knowledge concerns the knowledge of the mind. Today, neurosciences are making great strides and they are contributing significantly to make us understand, better and better, the functioning of the brain and its skills and ways of learning (BONCINELLI, 2011). As you can see, the world of epistemology is in constant bustle and, almost daily, it gives us new scientific discoveries. However, in our opinion, Morin has supported a valid thesis about it. He says that it is true that for our knowledge there is mind-brain recursion, but it is also true that there is the relationship between computation and cogito and that the latter depends on culture which makes possible the exchange between mind and brain. The process of knowledge is, therefore, so complex that it cannot be reduced to epistemologies, even to the most refined ones. The protagonist of knowledge is always a subject with mind and brain, but also with culture, feelings, emotions, passions and so on. This complexity requires a didactic and pedagogical intervention that cannot be reduced to a simple mechanical teaching-learning process. 
From what has been said, it is easy to understand that disciplinary teaching must not be subjected to epistemology. If it were, in fact, it would depend exclusively on it and the educational value conveyed by the discipline would disappear. The most qualified pedagogical and didactic studies (LANEVE, 2003) highlight that in teaching there is more than one variable which influences the didactic action: the pupil and his cognitive-emotionalintellectual outcome, the context and its multiple interdependencies.

\section{The pedagogical-educational telos in didactic action}

If, therefore, it is essential for disciplines and disciplinary teaching to focus their attention on the structures which allow the discipline to offer conceptual categories for learning, it is also essential that pedagogy and teaching draw their attention to the educational value of learning and that they do it through their own elaborations and not depending on the disciplines.

In short, as we will see, there is a pedagogical view on the disciplines, on the disciplinary didactics, which is by no means negligible for its educational value, as it has been well underlined by recent and older masters of pedagogical thought.

Outlining the scientific nature of pedagogy and, therefore, identifying its sources, Gino Corallo (1910-2003), raises the question of didactics as a transmission problem, but warning that "knowledge [...] to which teaching aims, is so closely linked with the (educational) act of freedom, that the didactic transmission, formally distinct from the act of education, is nevertheless concretely an integral part of it, as an indispensable content. [...] keeping education distinct from education, an existential connection between the two aspects of the same act is nevertheless possible and necessary [...]" (CORALLO, 2010, p. 301). Therefore, Corallo warns that the "masterly causality" (CORALLO, 2010, p. 301) which stimulates personal freedom and spontaneity, requires method and methodologies, which he also pays attention to, but above all it involves the pedagogical and educational intentionality.

Another "master", G. Acone reminds the need to find a lost Paideia and, therefore, "a training culture of a society in a certain historical period" (ACONE, 2005, p. 102) and in this perspective he emphasizes a pedagogy which, with its biological, psychological, sociological, anthropological, philosophical transits affects teaching seen as a "neighbouring field", in short, as a boundary and a limit line. Acone perceives the tendency of teaching to become self-sufficient with respect to pedagogy as a danger and this is not for a public defence of the 
pedagogical, but for the effects it can cause: if didatics believes that teaching is sufficient in itself, it makes the technical paradigm prevail by excluding horizons of meaning concerning education precisely elaborated by pedagogy. It is limited to education and it neglects education. Acone affirms the need for a pedagogy which knows how to be a horizon of educational meaning for man and which knows how to distinguish what belongs to education from what concerns education, development, socialization, learning, training" (ACONE, 2005, p. 26).

Alberto Granese in The Educational Conversation (GRANESE, 2008) also deals with the delicate relationship between pedagogy and didactics and he maintains that:

[...] if under a well recognizable and shareable profile, didactic competence is precious $[\ldots]$; in other cases the mere reliance on methodologies $[\ldots]$ involves a weakening or a disavowal of the necessary requirements for formative communication. The pros and cons of didactic objectification must be carefully evaluated, and this evaluation cannot be made in terms of a general philosophy of education, but it requires a balanced counterweight of the relationships between objectification and the persistence of the centripetal element, not objectifiable which is the basis of every communication experience and which guarantees its meaning, just as it guarantees the sense of the same objectification, since objectification is an irrepressible need of the subject. (GRANESE, 2008).

Granese (2008) understands the core of the problem and he points out and hopes "that the educational objectification must become compatible with the non-objectifiable existential subjectivity" (GRANESE, 2008) and calls upon this requirement by pedagogical and didactic scholars. The relationship between the pedagogical and the didactic is a synthesis of subjectivity and objectivity and this synthesis occurs with education and not with instruction as it happened instead with "the scholastic stylization of pedagogical thought in a precisely determined historical period concerning the social organization of learning" (GRANESE, 2008).

Now, it is natural to ask a question which has not got an easy solution: teaching practice must be educational and for this reason teaching techniques are a necessary condition but not a sufficient one. It is necessary to have a clear educational meaning which is present in the praxis of teaching, it is often an implicit meaning because "in the act of the teacher there is much more than the teacher knows and can govern, a universe of affections, tensions, assumptions of common sense, beliefs, naive epistemologies, abductive reasoning strongly connected with self-image and social existence which make teaching practice something very different from an engineering project" (GRANESE, 2008). From this fact we deduce that 
teaching as a practice is imbued with pedagogy. It is, therefore, on the level of practice that pedagogy and teaching find a common basis.

The pedagogy of praxis will be careful to analyze, realize, understand the act, the action, the implementation of teaching activity and following this path it can also go into studying the teaching praxeology. In this way, the pedagogy of praxis will search for the meaning of the teaching act, overcoming the ideological, dogmatic and deterministic pedagogies, and giving useful elements for the configuration of the "competent" teacher on a pedagogical-hermeneutic level.

The attention, therefore, will be directed to the actions that the teacher performs when teaching and this focus will highlight the importance of the hermeneutic attitude the teacher must endorse.

Nowadays, teaching needs a teacher with hermeneutic-oriented skill, that is, he/she must be willing and ready to cooperate interactively through dialogue and listening in his/her didactic action. During a lesson, the teacher must activate the Gadamerian hermeneutic circularity thanks to which the whole and the parts find a meeting point in sharing horizons of meaning (PERLA, 2010, p. 2010).

The lesson done according to hermeneutic principles will enhance each one's point of view, it will search for negotiation of meanings, engage in giving meaning to the learnt knowledge. It will be a lesson which will invite you to the hermeneutic "reading" of the context, of the historical situation in which you live. Didactic hermeneuticity will start from prejudices not to remain fixed in them, but to become aware of them and to overcome them. It will be a didactic aimed at deconstructing the obvious, the banal, the routine and it will take charge of elaborating knowledge processes also drawing from the experience of which each one is the bearer. The discussion and the dialectic are fundamental for the conception, elaboration and realization of the educational projects. The hermeneutic phrónesis can, without any doubt, help the teacher to avoid the contradictions and to search for the educational consensus on proposals which must always involve the full participation of the learners. The hermeneutic attitude, both in teaching and in peer relations, supports the professional growth of the teacher who will have a professional knowledge characterized not only by épisteme, or a logically and scientifically founded knowledge, but also by a téchne inspired by phrónesis, an expert know-how, wise, knowledgeable, able to promote the formation of the subject/person in its entirety and humanity. 


\section{REFERENCES}

ACONE, G., La Paideia introvabile, La Scuola, Brescia 2004.

ACONE, G., L'orizzonte teorico della pedagogia contemporanea, Edisud, Salerno 2005.

ALTET, M., L'analyse de pratiques: retrospective et questions actuelles, in "Recherche et formation", 51, 2006, pp. 11-25.

ALTET, M. et al., Formare gli insegnanti professionisti, tr. it., Armando, Roma 2006.

BACHELARD, G., Le nouvel esprit scientifiqu, Paris, 1934 (Italian translation edited by Laterza, Bari 1951).

BALDACCI, M. (ed.), La formazione dei docenti in Europa, Mondadori, Milano 2010.

BALDACCI, M., Il Sistema formativo e il curricolo scolastico, in M. Baldacci, M. Corsi (eds), Sistema formativo ed emergenze dell'educazione, Tecnodid, Napoli 2010.

BINANTI, L.; TEMPESTA, M. (eds.), La formazione del docente nella scuola europea del terzo millennio, Pensa Multimedia, Lecce 2011.

BONCINELLI, E., La vita della nostra mente, Laterza, Roma-Bari 2011.

BRUNER, J., The Process of Education, Mass.: Harvard University Press, Cambridge 1960.

CORAllO, G., Pedagogia, vol. I, L'educazione. Problemi di pedagogia generale, Armando, Roma 2010.

DAMIANO, E., La Nuova Alleanza. Temi problemi prospettive della nuova ricerca didattica, La Scuola, Brescia 2006.

DAY, C.; LANEVE, C. (eds.), Analysis of Educational Practices. A comparison of Research Models, La Scuola, Brescia 2011.

FABBRI, L., Formazione degli insegnanti e pratiche riflessive, Armando, Roma 1999.

GERMAIN, P., Sur quelques cararactéristiques des disciplines and sur la portée de la science in "Les études philosophiques", 2, 1978, pp. 157-170.

GRANESE, A., La conversazione educativa, Armando, Roma 2008.

KUHN, Th.S., The Structure of Scientific Revolutions, University of Chicago Press, Chicago 1962; tr. it., La struttura delle rivoluzioni scientifiche, Einaudi, Torino 1969.

LANEVE, C., Per una teoria della didattica. Modelli e linee di ricerca, La Scuola, Brescia 1993.

LANEVE, C., Il campo della didattica, La Scuola, Brescia 2000. 
LANEVE, C., La didattica fra teoria e pratica, La Scuola, Brescia 2003.

LANEVE, C., Manuale di didattica. Il sapere sull'insegnamento, ELS-La Scuola, Brescia $2017^{2}$.

LIGORIO, B., Come si insegna, come si apprende, Carocci, Roma 2003.

MORTARI, L., Ricercare e riflettere. La formazione del docente professionista, Carocci, Roma 2009.

PAGANO, R., Il pensiero pedagogico di Gaetano Santomauro, La Scuola, Brescia 2008.

PAGANO, R., Educazione e interpretazione. Profili e categorie di una pedagogia ermeneutica, ELS-La Scuola, Brescia 2018.

PERLA, L., Didattica dell'implicito, La Scuola, Brescia 2010.

PERLA, L. Tempesta M. (eds.), Teacher Education in Puglia. Università e scuola per lo sviluppo della professionalità docente, Pensa MultiMedia, Lecce 2016.

PERRENOUD, $\mathrm{Ph}$., La formation des enseignants entre théorie et pratique, L'Harmattan, Paris 1994.

POSTIC, M., Observation et formation des enseignants, PUF, Paris 1977.

RIVA, M.G. (ed.), L'insegnante professionista dell'educazione e della formazione, ETS, Pisa 2008.

SCHIEDI, A., Narrare la Bildung. L'itinerario pedagogico di Edith Stein, ELS La Scuola, Brescia 2017.

SCHÖN, D., Formare il professionista riflessivo, tr. it., FrancoAngeli, Milano 2006.

STEIN, E., Bildung und Enfaltung der Individualität, Verlag Herder, Freiburg im Breisgau; tr. it. edited by A. Ales Bello and M. Paolinelli, Formazione e sviluppo dell'individualità, Città Nuova, Roma 2017.

\section{$\underline{\text { ABOUT THE AUTHORS: }}$}

\section{Riccardo Pagano}

Full Professor of General and Social Pedagogy at the University of Bari Aldo Moro - Ionian Department in Legal and Economic Systems of the Mediterranean Area. Society, environment, cultures - Deputy Director of the Ionian Department and of the Cirped - Centro italiano di Ricerca pedagogica (Italian Centre for Educational Research). Professor of Political Education in the Master's Degree in Law and Human Resources and Professor of Planning and Training in the Economics and Business Administration Course at the University of Bari Aldo Moro - Ionian Department. He is the author of over 150 national and international publications, including monographs, contributions in volumes and articles in 
journals and magazines, many of which are A-class. His latest works include: Il pensiero pedagogico di Antonio Gramsci [Antonio Gramsci's pedagogical thought] (Monduzzi, 2013) - and Manuale di pedagogia. Temi e ambiti di ricerca e prassi educativa [Manual of Pedagogy. Topics and areas of research and educational practice], with H.A. Cavallera, (EdiSES, 2013). E-mail: riccardo.pagano@uniba.it

(iD http://orcid.org/0000-0001-7694-8613

\section{Adriana Schiedi}

Researcher in General and Social Pedagogy at the University of Bari Aldo Moro - Ionian Department in Legal and Economic Systems of the Mediterranean Area. Society, environment, cultures, already having the National Scientific Qualification as Second Level Professor in the sector concerning competitive exams 11/ D1 - Pedagogy and History of Pedagogy - SSD M-PED / 01 - Professor of General and Intercultural Education in the Course of Legal Sciences for Immigration, Human Rights and Interculturality - University of Bari Aldo Moro - Ionian Department in Legal and Economic Systems of the Mediterranean Area. Society, environment, cultures. She has been collaborating for years with the chair of General Pedagogy as an expert on the subject in the courses of Laws and Economics, respectively in the courses of Political Education and Planning and Training of Human resources. She is the author of numerous essays and articles in qualified national and international journals and magazines. She carries out studies and researches mainly on epistemology and on the methodology of pedagogical research. As for the latter, she privileges to focus her attention on the phenomenological style of investigation and the narrative approach (ethnographic, selfethnographic and autobiographical) applied to educational matters and issues. As for phenomenology, she has been able to grasp, in several contributions, the strong pedagogical value that she intended to highlight starting from a careful examination of the Bildung theory by Edith Stein. Her volumes include: Narrare la Bildung. L'itinerario pedagogico di Edith Stein. [Narrate the Bildung. The pedagogical itinerary of Edith Stein] (2017) - La valutazione nella scuola. Aspetti, modelli ed esperienze [Evaluation at school. Aspects, models and experiences] (2013) - Pensare, sentire ed agire pedagogicamente [Thinking, feeling and acting pedagogically] (2013) - Psicologia e Scienze dell'Educazione nella scuola secondaria [Psychology and Educational Sciences at high school] (2013) - La pratica di insegnamento. Nuovi percorsi di lettura [The teaching practice. New reading paths] (2010). E-mail: adriana.schiedi@uniba.it

\section{iD http://orcid.org/0000-0001-9478-9011}

Recebido em: 03 de maio de 2020 Aprovado em: 18 de setembro de 2020 Publicado em: 01 de dezembro de 2020 